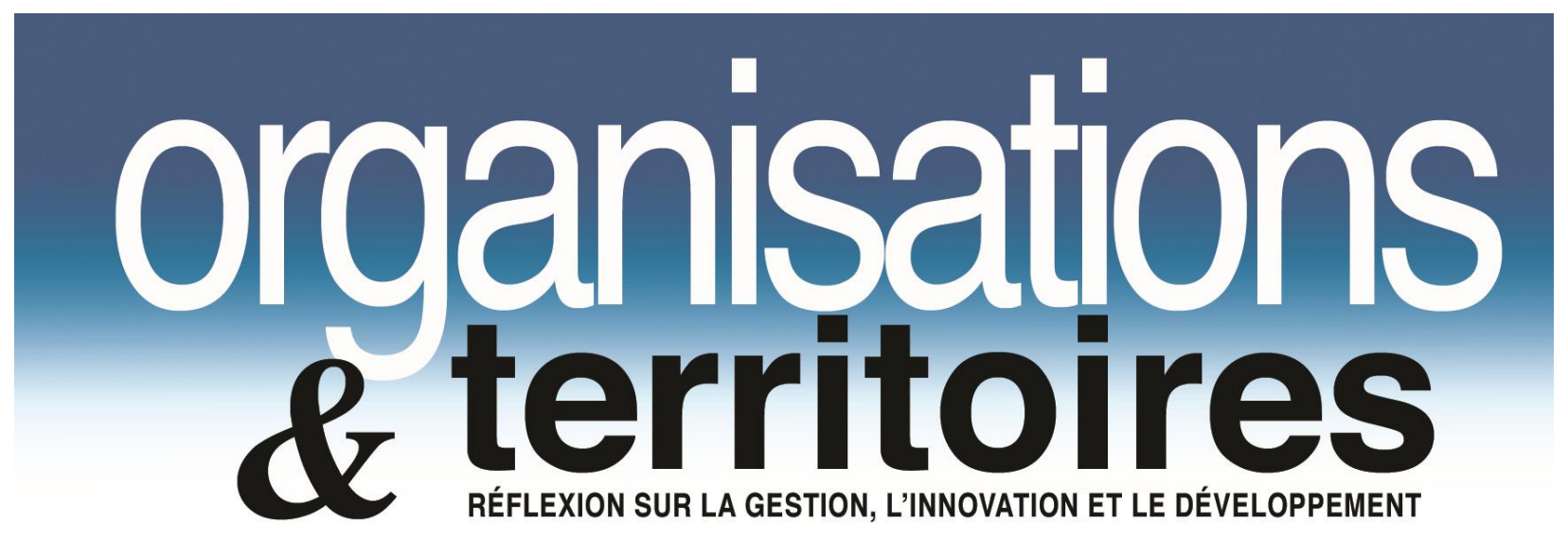

\title{
ERRATUM
}

\section{Volume 17, numéro 2 - Été 2008}

«Projets cliniques territoriaux des CSSS et participation des acteurs de la société civile » Alex Ellyson et Denis Bourque

Un paragraphe a malencontreusement été coupé lors de l'édition. Nous publions à nouveau cet article en page 77 avec le texte manquant. 